\title{
PENINGKATAN KAPASITAS KELEMBAGAAN PETANI MELALUI PENDAMPINGAN PEMBENAHAN ADMINISTRASI DIKAWASAN FOOD ESTATE PROVINSI KALIMANTAN TENGAH
}

\author{
SEPTIANA \\ Widyaiswara Balai Pelatihan Pertanian Lampung- Kementrian Pertanian \\ e-email : sevtie182020@gmail.com
}

\begin{abstract}
ABSTRAK
Tujuan dari kegiatan pengabdian masyarakat petani berupa pendampingan pada purnawidya pelatihan adalah salah satunya untuk meningkatkan pengetahuan, keterampilan dan sikap dari para petani di daerah/kawasan food estate Provinsi Kalimantan Tengah. Kegiatan Pendampingan yang dilakukan berupa pembenahan adminitrasi pembukuan kelompok yang mencakup pembukuan kegiatan dan pembukuan keuangan yang dilaksanakan pada Bulan November 2020 selama 7 (tujuh) hari efektif. Dalam pelaksanaan dilapangan terdapat beberapa kelompok yang berhasil dibenahi administrasinya, antara lain : Lembagan Keuangan Desa "Sukses Selalu" di Desa Bina Jaya (A1), "Koperasi KEP Harapan Baru Sejahtera" di Desa Harapan Baru (A4) dan Koperasi Produksi Pertanian "Bernah Nusa Bakti” di Desa Bentuk Jaya (A5) Kecamatan Dadahup Provinsi Kaliamantan Tengah. Dari hasil pendampingan yang dilakukan terdapat beberapa pembukuan administrasi kelembagaan tani yang telah berhasil dibuat yaitu: 1) Buku Induk Anggota Kelompok, 2) Buku Tamu, 3) Buku Daftar Hadir Pertemuan, 4) Buku Notulensi Rapat, 5) Buku Kegiatan, 6) Buku Inventaris Barang, 7) Buku Iuaran Anggota, dan 8) Buku Kas Umum Kelembagaan Tani. Berdasarkan Evaluasi dan monitoring yang terus dilakukan pasca kegiatan pendampingan tersebut berakhir, kelembagaan-kelembagaan tani tersebut telah dapat mengaplikasikan mendapatkan manfaat dari catatan-catatan buku adminitrasi yang mereka buat untuk mengontrol kemajuan dari kelembagaan tani yang petani ikuti agar kelembagaan tersebut dapat kuat, tangguh dan mandiri Kata Kunci: Kapasitas Kelembagaan Tani, Pembenahan Administrasi, Food Estate
\end{abstract}

\section{PENDAHULUAN}

Sejak tahun 2020 hingga lima tahun kedepan, pengembangan korporasi petani menjadi salah satu program pembangunan strategis yang menjadi fokus utama dari kegiatan Kementrian Pertanian. Melalui Mentri Pertanian RI Bapak Syahrul Yasin Limpo, Presiden Jokowi mengintruksikan untuk mewujudkan kemandirian pangan dengan salah satu tujuannya adalah meningkatkan kesejahteraan petani (Kementan, 2020).

Program Food Estate mengembangkan konsep pertanian mulai dari hulu sampai ke hilir, kluster berbasis korporasi petani, diversifikasi pangan, hortikultura, ternak, lumbung pangan nasional dan pertanian modern melalui mekanisasi dan pertanian 4.0 yang tercover dalam Program Food Estate. Untuk lokasi Program Food Estate di Provinsi Kalimantan Tengah khususnya Kabupaten Pulang Pisau dan Kabupaten Kapuas dan Kabupaten Dadahup adalah salah satu kecamatan di Kabupaten Kapuas yang menjadi salah satu sentra Program Food Estate Kalimantan Tengah yang petaninya diarahkan untuk membentuk korporasi petani.

Bicara tentang korporasi, tentu tidak dapat dipisahkan dari peran petani yang tergabung dalam kelompok tani. Kelompok tani juga difinisikan sebagai sebuah kelembagaan ditingkat petani yang dibentuk untuk mengorganisir para petani dalam berusahatani. (Hermanto dan Swastika, 2011). Pemberdayaan petani akan lebih efektif bila dilakukan melalui sebuah wadah, yaitu kelompok tani. Hal ini sesuai dengan Permentan Nomor 82 tahun 2013 tentang Kelompok Tani dan Gabungan Kelompok Tani. Kelompok-kelompok tani yang didorong untuk berkorporasi harus memiliki tata kelola administrasi yang baik terlebih dahulu agar kedepannya dapat menjadi kelembagaan petani yang kuat, maju serta mandiri.

Perangkat administrasi kelembagaan yang baik dan benar diperlukan sebagai bahan informasi bagi kelompok maupun pihak lain yang berkaitan dengan kelompok itu, seperti : 
usaha, permodalan, jaringan kerjasama dan lain-lain. Sebuah organisasi kelembagaan petani yang kuat dan maju sudah sepatutnya mempunyai administrasi kelompok yang baik dan benar untuk menunjang semua aktivitas yang dilakukan kelompok tersebut (Suteno dan Rabiansyah H, 2020).

Administrasi kelembagaan petani merupakan aspek utama dalam pendirian dan pengembangan sebuah kelembagaan petani. Administrasi kelompok dapat digunakan untuk memonitor penumbuhan, pengembangan dan pelaksanaan kegiatan kelembagaan petani. Administrasi merupakan segenap rangkaian usaha bersama yang dilaksanakan sekelompok orang dalam wadah organisasi untuk mencapai suatu tujuan.

Dalam penguatan kapasitas kelembagaan petani dapat dilakukan dengan pembenahan administrasi kelompok tani. Kelompok tani merupakan kelembagaan di tingkat petani yang dibentuk untuk secara langsung mengorganisir para petani dalam berusahatani. Kelompok tani dibentuk oleh dan untuk petani, guna mengatasi masalah bersama dalam usahatani serta menguatkan posisi tawar petani, baik dalam pasar sarana maupun pasar produk pertanian. Kelompok tani itu sendiri memiliki fungsi sebagai wadah belajar bagi anggotanya guna meningkatkan pengetahuan, keterampilan, dan sikap petani dalam meningkatkan usahataninya. Selain itu, kelompok tani juga berfungsi sebagai wahana kerjasama diantara sesama petani dalam kelompok tani dan antar kelompok tani, serta dengan pihak lain (Suteno dan Rabiansyah H, 2020). Administrasi kelompok tani merupakan seperangkat dokumen ataupun catatan yang menyangkut semua kegiatan yang dilaksanakan oleh kelompok tani tersebut.

Dalam perangkat administrasi dibedakan menjadi dua bagian pokok yaitu: administrasi kegiatan dan administrasi keuangan. Dalam administrasi kegiatan, segala catatan yang dilakukan oleh kelompok berkaitan dengan kegiatan kelompok diluar urusan keuangan. Sedangkan administrasi keuangan, segala catatan yang khusus berkaitan dengan keuangan kelompok (Kementrian Pertanian, 2014).

Berdasarkan pada program strategis diatas, petani yang juga tergabung dalam kelembagaan petani (kelompok tani, koperasi pertanian, dan Gapoktan) sebagai pelaku dan sasaran utama dari program harus mendapatkan pendampingan dari berbagai pihak termasuk widyaiswara agar program yang dikucurkan dapat berhasil dan tepat sasaran. Kelompok tani dianggap sebagai organisasi yang efektif untuk memberdayakan petani, meningkatkan produktivitas, pendaapatan dan kesejahteraan petani dengan bantuan fasilitas pemerintah melalui program dan kebijakan pembangunan pertanian (Nuryati S dan Swastika D, 2011).

Widyaiswara sebagai agen of change atau agen perubahan yang salah satu tugasnya adalah meningkatkan kompetensi penyuluh serta petani terpanggil untuk melakukan kegiatan pendampingan secara khususs pada penyuluh dan petani di Program kawasan Foof Estate khususnya Kecamatan Dadahup Provinsi Kalimantan Tengah baik secara langsung mendatangi lokasi penyuluh dan petani itu berada maupun melalui media sosial.

\section{METODE PELAKSANAAN}

Kegiatan ini adalah kegiatan pengabdian masyarakat, berupa pendampingan pasca pelatihan khususnya masyarakat tani yang dilakukan oleh Widyaiswara BBPP Binuang kepada kelompok tani dan kelembagaan ekonomi petani (KEP) yang ada di daerah sentra food estate di Kalimantan Tengah khusunya Kecamatan Dadahup sebagai lokasi pengabdian, dimana pada beberapa kelembagaan tani tersebut belum sama sekali/sudah punya tetapi belum tertata dengan baik terkait pembukuan administrasi yang mereka miliki. Masih terbatasnya administrasi kelembagaan yang dimiliki oleh kelembagaan tani dan KEP tersebut menjadi dasar dilaksanakannya kegiatan pengabdian ini. Kegiatan Pengabdian pada petani ini tepatnya dilaksanakan di Desa Bentuk Jaya (A5) dengan Koperasi Produksi Pertanian "Bernah Nusa Bakti", Desa Bina Jaya (A1) dengan Lembagan Keuangan Desa "Sukses Selalu" dan Desa Harapan Baru (A4) dengan "Koperasi KEP Harapan Baru Sejahtera". 


\section{Tahapan Kegiatan Pengabdian Masyarakat (Pendampingan)}

Berdasarkan kondisi administrasi kelembagaan yang ditemui dilapangan, sebagian besar tata kelola administrasi yang petani miliki sebenarnya sudah ada, tetapi belum dikelola secara maksimal dan pencatatan yang dilakukan hanya diletakkan pada satu buku serta tidak mengikuti format buku yang di sarankan secara baku. Maka metode kegiatan yang pertama kali dilakukan adalah dengan diadakannya kegiatan pelatihan terkait pengelolaan pengorganisasian kelembagaan tani. Dalam kegiatan pelatihan tersebut materi yang diajarkan adalah tentang pengorganisasian kelompok tani, aturan-aturan kelompok tani yang dalam hal ini tertuang dalam Anggaran Dasar (AD) dan Anggaran Rumah Tangga (ART) Kelompok Tani serta Administrasi Kelompok Tani.

Setelah minimal 3 (tiga) bulan kegiatan pelatihandilaksankan, melalui form Rencana Tindak Lanjut (RTL) yang petani isi ketika pelatihan akan usai dapat dilihat kembali sejauh mana tingkat pelaksanaan dan penerapan pelatihan yang telah dapat dilakukan oleh petani selaku purnawidya dari pelatihan yang pernah dikutinya. Berikut ini disajikan diagram pelaksanaan kegiatan pengabdian masyarakat berupa pendampingan pasca pelatihan pada petani yang tergabung dalam kelembagaan tani yang ada di Kecamatan Dadahup Kabupaten Kapuas Provinsi Kalimantan Tengah.

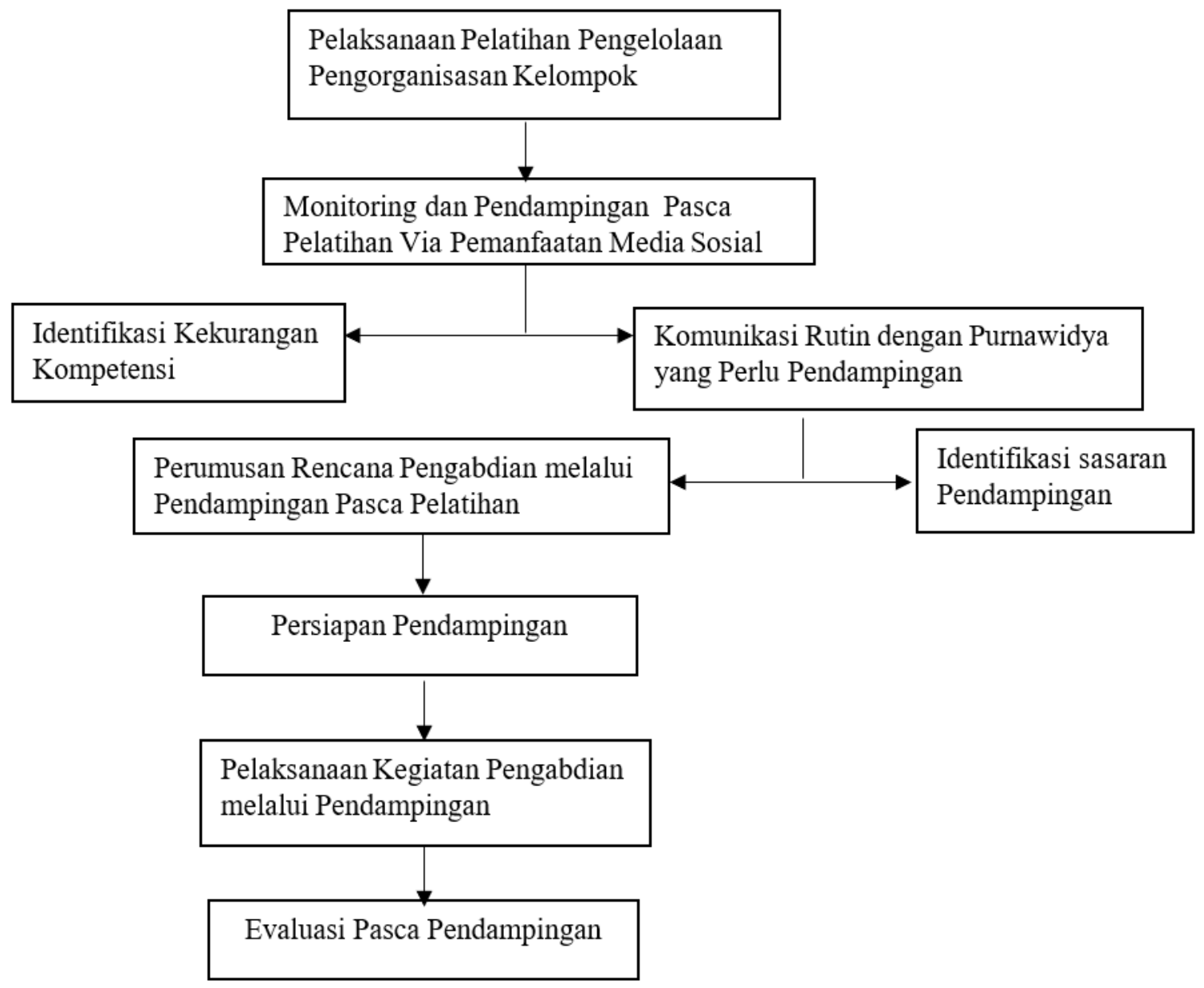

Gambar 1. Diagram Alur Pelaksanaan Pendampingan Kelembagaan Tani

\section{HASIL DAN PEMBAHASAN}

Dalam mencapai tujuan dari pelaksanaan kegiatan pengabdian pada masyarakat petani berupa pendampingan tata kelola addministrasi kelembagaan tani, terdapat 7 (tujuh) tahapan yang dilalui, yaitu: 


\section{Pelaksanaan Pelatihan}

Petani yang memiliki pengetahuan, keterampilan, dan tindakan terhadap potensi yang dimilikinya merupakan petani berdaya. Untuk mencapai keberdayaan tersebut, petani diarahkan untuk mengikuti berbagai macam kegiatan pemberdayaan yang diadakan beberapa unsur ataupun instansi terkait, misalnya kegiatan pemberdayaan yang dilakukan oleh penyuluh pertanian di wilayah kerjanya, ataupun beberapa instansi terkait yang membawahi kegiatan pemberdayaan tersebut dengan tujuan dapat meningkatkan tingkat pengetahuan, keterampilan, dan kreativitas dari petani sasaran pemberdayaan ataupun pendampingan.

Sumodiningrat (1999), proses menuju keberdayaan petani dilihat dari beberapa sudut pandang di antaranya: Menciptakan iklim atau suasana yang memungkinkan petani berkembang; Peningkatkan kemampuan petani dalam membangun melalui bantuan dana, pelatihan, pembangunan sarana, prasarana baik fisik maupun sosial, dan pengembangan kelembagaan daerah; Perlindungan dengankeberpihakan pada petani yang lemah; Menciptakan kemitraan yang saling menguntungkan.
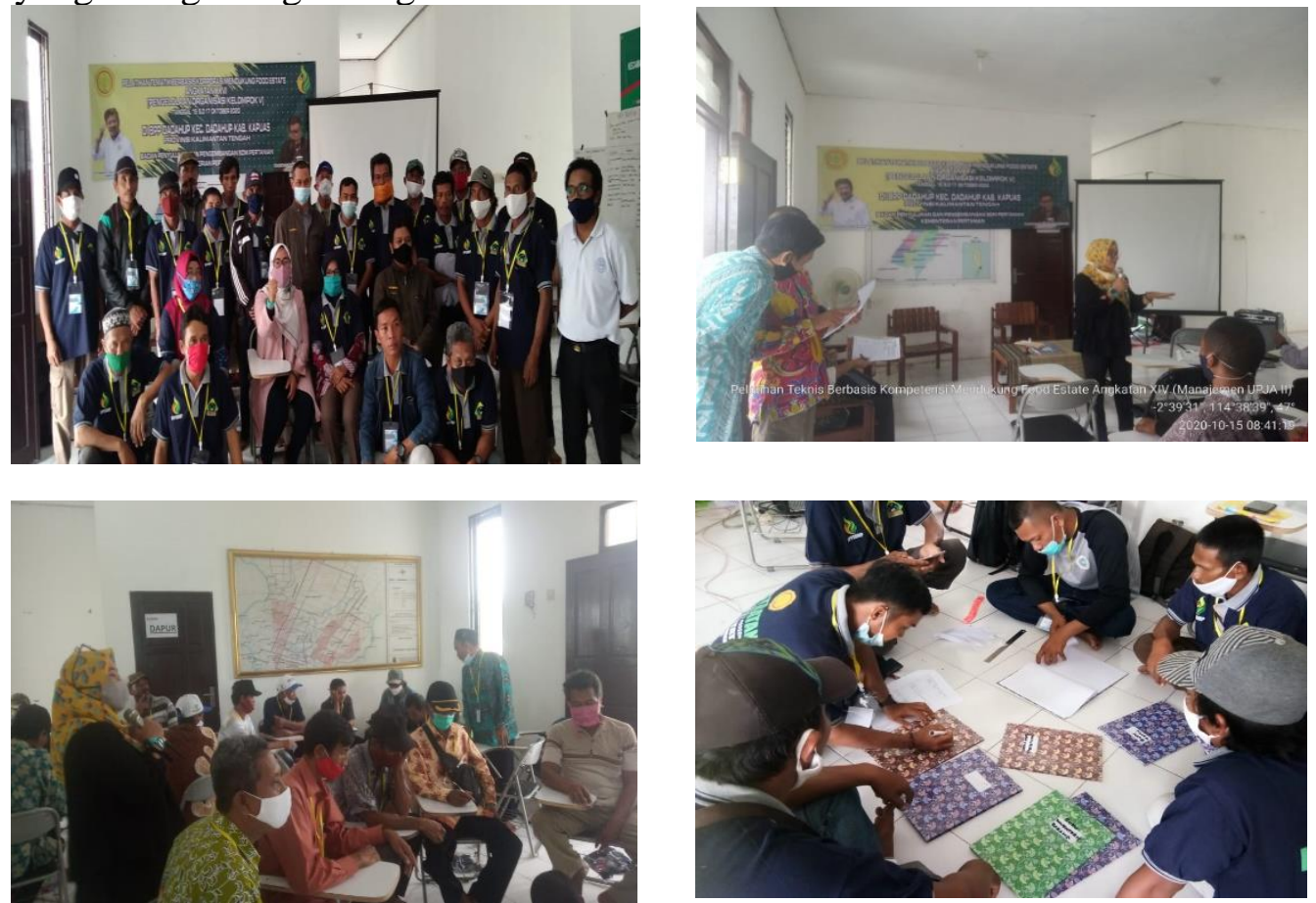

\section{Gambar 2. Foto-foto Kegiatan Pelatihan Pengelolaan Pengorganisasian Kelembagaan Tani}

Dalam kegiatan pelatihan yang diselenggarakan oleh Balai Besar Pelatihan Pertanian Binuang di Kecamatan Dadahup ini merupakan, salah satu upaya dalam meningkatkan pengetahuan dan keterampilan dari petani sasaran pelatihan, dan proses pendambingan yang dilaksanakan pasca pelaksanaan pelatihan merupakan salah satu pentuk pemberdayaan ataupun pengebdian pada masyarakat khususnya masyarakat tani.

Pelaksanaan Pelatihan Pengelolaan Pengorganiasasian Kelompok Tani dilaksanakan di BPP Dadahup selama 3 (tiga hari) dan diikuti oleh petani sebanyak 30 (tiga puluh) orang yang merupakan pengurus kelembagaan tani yang berasal dari utusan setiap kelembagaan/kelompok tani di Kecamatan Dadahup Provinsi Kalimantan Tengah. Selama pelatihan berlangsung, peserta secara aktif mengikuti setiap materi yang disampaikan oleh para pelatih/fasilitator dan widyaiswara. Metoda pelaksanaan pelatihan yang digunakan sesuai dengan Permentan No. 37/SM.120/8/2018 Tentang Pedoman Pelatihan Pertanian yaitu Experiential Learning Cycle (ELC) atau AKOSA (Alami, Kemukakan, Olah, Simpulkan, Aplikasikan) dengan pendekatan pembelajaran orang dewasa/Andragogy yang bersifat pembaharuan. Pendekatan sebagaimana dimaksud dilakukan dalam bentuk ceramah, diskusi, curah pendapat, praktik,dan penugasan. 
Selanjutnya Fasilitator/Pelatih/Narasumber pada pelatihan ini berasal dari dari Ditjen Tanaman Perkebunan Jakarta, Disbunak Kabupaten Banjar dan Widyaiswara Balai Besar Pelatihan Pertanian Binuang Kalimantan Selatan.

\section{Monitoring dan Pendampingan Via Pemanfaatan Media Sosial}

Proses monitoring dan pendampingan yang dilakukan setelah selesainya kegiatan pelatihan dilakukan dengan menafaatkan media sosial yang berkembang saat ini, yaitu melalui aplikasi Whats App Group, telpon,, SMS, Inastagram (IG), email dan facebook yang dimiliki oleh pelatih/widyaiswara dan peserta pelatihan. Dengan memanfaatkan media sosial, komunikasi dan korespondensi dengan petani masih terhubung dan dapat menjadi salah satu sarana yang dapat dipergunakan sesama peserta dalam memecahkan kesulitan ataupun masalah yang mereka hadapi dalam berusaha tani. pariwisata. Dengan kata lain Media sosial dalam perkembangan nya sangat memudahkan semua orang untuk berkomunikasi, berpartisipasi, saling berbagi, dan membentuk suatu jaringan online (Zarella: 2010). Dan Widyaiswara juga dapat berperan aktif dalam media tersebut.

Dalam manfaatkan sosial media yang ada, ternyata tidak semua purnawidya dapat dengan maksimal memanfaatkannya. Disinilah diperlukan peran pelatih/widyaiswara untuk terus menanyakan apasaja kendala ataupun kesulitan yang dihadapi para purnawidya tersebut.

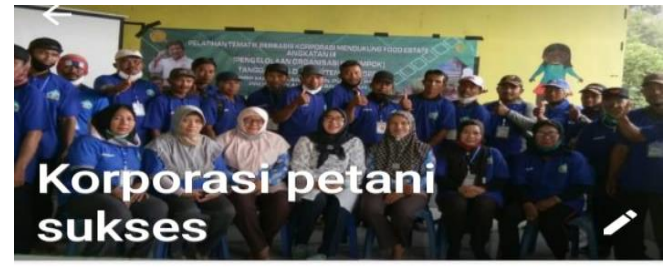

Tambah deskripsi grup

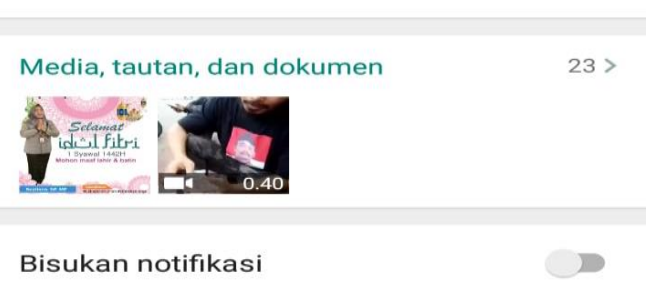

Notifikasi kustom

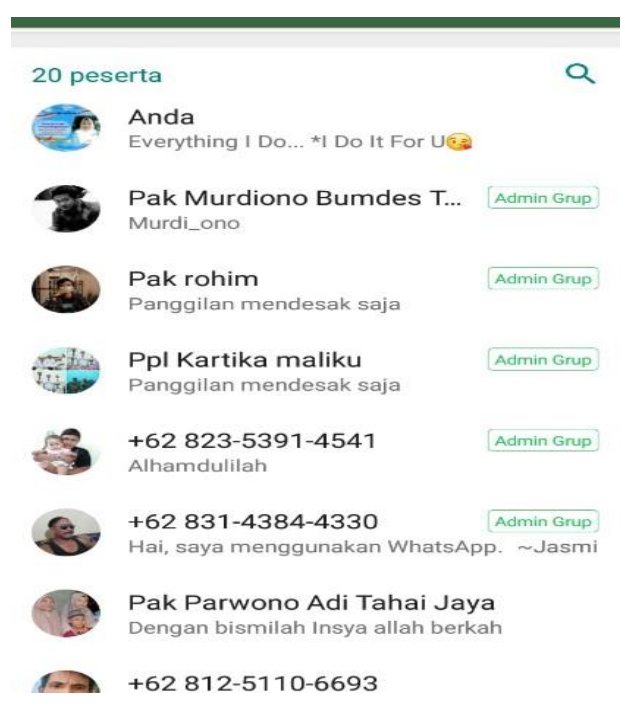

Gambar 3. WAG Korporasi Petani yang Menjadi Sarana Berkoordinasi dan Berkomunikasi Selama dan Pasca Pelatihan

Sosial media yang lebih sering dimanfaatkan oleh para purnawidya pelatihan adalah Whats App Group. Dalam WAG Korporasi Petani Sukses ini, purnawidya pelatihan sering menanyakan hal-hal yang tentang bagaimana proses pembentukan BUMP (Badan Usaha Milik Petani) hingga memiliki legal hukumnya, sehingga petani memiliki posisi yang kuat dan memiliki nilai tawar dalam menentukan harga komoditas pertanian yang mereka hasilkan. Hanya beberapa purawidya petani milenial yang dapat mengakses sosial media IG dan memanfaatkan informasi-informasi yang terdapat di IG tersebut untuk digunakan dalam menambah ilmu pengatahuan mereka terkait bidang pertanian.

Selama proses pendampingan via sosial media, sudah dapat diidentifikasi siapa saja dari purnawidya pelatihan tersebut yang masing sangat kurang memehami serta belum dapat mengaplikasikan hasil pelatihan sesuai dengan yang dihaparapkan. Atau bisa juga diidentifikasi sasaran purnawidya yang memerlukan pendampingan lebih untuk tahap selanjutnya dalam menerapkan hasil pelatihan di lokasi purnawidya berada. 


\section{Identifikasi Sasaran dan Perumusan Rencana Pendampingan}

Selanjutnya setelah proses identifikasi materi yang kurang dipahami oleh purnawidya, dapat diidentifikasi siapa saja dari purnawidya tersebut yang sangat memerlukan pendampingan mendalam dilapangan. Setelah didapatkan siapa saja sasaran pendampingan, mulai dapat dirumuskan bagaimana teknis pendampingan yang akan dilakukan, mulai dari waktu (tanggal dan jam), tempat, banyaknya anggota sasaran yang akan dikumpulkan dan lain sebagainnya. Selain itu dapat juga di rumuskan siapa saja petugas serta widyaiswara yang terlibat dalam pelaksanaan kegiatan pendampingan tersebut.

\section{Persiapan Pendampingan}

Pada tahap ini mulai dilakukan persiapan pelaksanaan pendampingan dengan tetap mengkomunikasikan dengan purnawidya sasaran dan pihak instansi terkait misalnya Dinas Pertanian Kabupaten Kapuas dan pihak BPP Dadahup yang membawahi wilayah kerja binaan patani di Kecamatan Dadahup. Dengan tetap mengkomunikasikan kegiatan pendampingan kepihak terkait tersebut, diharapkan apapun yang dilakukan widayaiswara dalam pengembangan kompetensi petani dan kelompok taninya akan tetap diketahui dan mendapatkan ijin. Terkait waktu dan teknis pelaksanaan pendampingan, dilaksanakan pada

\section{Pelaksanaan Kegiatan Pengabdian dengan Pendampingan}

Pada tahap ini, kegiatan pendampingan dilakukan secara jemput bola dengan mendatangi satu persatu lokasi kelembagaan (kelompok tani/Gapoktan/Koperasi Pertanian). Hal inis esuai dengan salah satu fungsi dari kelompok tani yaitu sebagai kelas belajar bagi sesama anggota kelompoknya dalam meningkatkan pengetahuan, sikap dan keterampilan yang dalam hal ini khusus belajar tentang pembenahan administrasi kelembagaan. Effendi L dan Apriani Y (2018) juga mengemukakan peranan kelompok tani yang merupakan wahana belajar bagi para petani serta media komunikasi sesama petani untuk meningkatkan efektivitas dan efisiensi proses adopsi inovasi teknologi pertanian, terjadinya peningkatan kualitas sumber daya manusia, sehingga diharapkan dapat mengembangkan usaha tani yang menguntungkan.

Dalam kegiatan pendampingan ke kelembagaan tani ini yang dilakukan adalah membantu mensosialisasikan administrasi kelembagaan tani yang lebih dalam pada semua anggota yang hadir, sehingga diharapkan tingkat pemahaman tentang pentingnya administrasi kelembagaan tani dapat dipahami bukan hanya oleh purnawidya pelatihan saja tapi dapat dipahami oleh sesua sasaran pendampingan yang hadir.

Setelah mensosialisasikan, peserta diminta membuat dan diajarkan bagaimana mengisi pembukuan administrasi tersebut. Terdapat beberapa buku dan bahan-bahan administrasi pembukuan lainnya yang diberikan pada sasaran pendampingan dan sasaran diminta langsung mempraktekkan kembali pembuatan pembukuan tersebut hingga contoh pengisian buku administrasinya. 

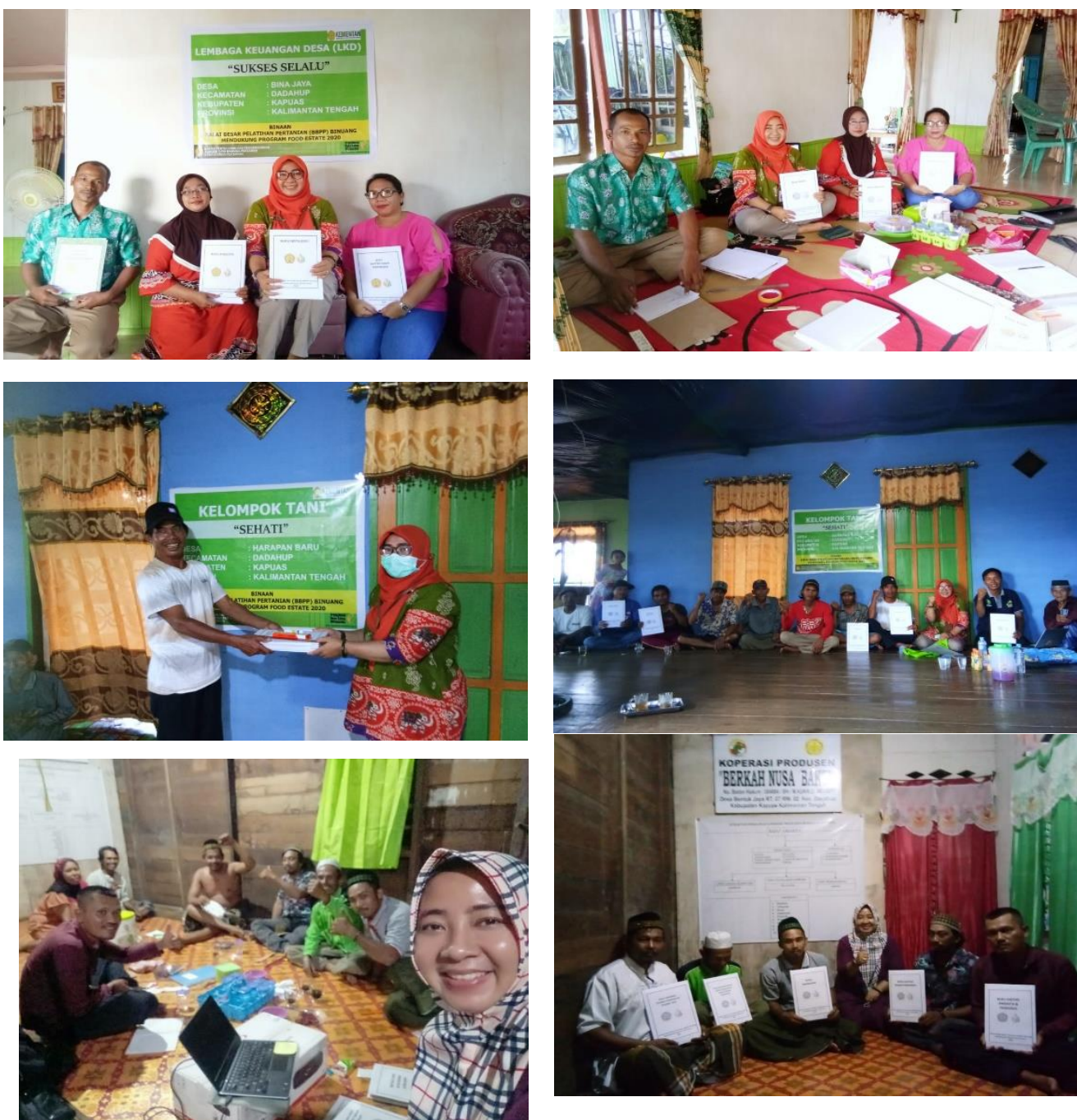

\section{Gambar 4. Foto-foto Dokumentasi Kegiatan Pendampingan Pasca Pelatihan di Kelembagaan tani sasaran}

\section{Evaluasi Pasca Pengabdian (Pendampingan)}

Pada tahap evaluasi pasca pendampingan ini, dapat dilihat dampak (hasil) kegiatan pendampingan yang dilakukan. Tujuannya adalah untuk menilai apakah kegiatan pendampingan sudah lebih menghasilkan pembenahan administrasi kelembagaan tani kearah yang lebih baik, tertata serta teratur sehingga kedepannya dapat menjadi alah satu faktor keberhasilan kelembagaan tani yang maju dan kuat.

Dari hasil evaluasi pelaksanaan pendampingan yang telah dilakukan, terlihat hasil yang cukup nyata dimana purnawidya sasaran pendampingan makin paham dan mengerti betapa pentingnya kelengkapan administrasi yang harus dimiliki oleh kelembagaan tani yang mereka ikuti. Tentu saja hal ini terdapat peran dari seluruh Petugas Penyuluhan Lapangan (PPL) yang memiliki wilayah kerja di Kecamatan Dadahup, dimana PPL tersebut secara aktif terus melakukan penyuluhan, pendampingan dan supervisi terkait perangkat administrasi kelembagaan tani. Kegiatan penyuluhan ini PPL lakukan baik dalam pertemuan-pertemuan rutin yang diadakan oleh kelembagaan tani maupun langsung di lahan usahatani milik petani. Hal ini senada dengan apa yang dikemukakan oleh Aria RA, Hasanuddin T, Prayitno RT (2016) Penyuluh pertanian lapangan (PPL) harus mampu berperan aktif dalam hal diseminasi informasi, melakukan fasilitasi, melakukan supervisi/ pemantauan, dan melakukan evaluasi.

Petani sangat menyadari administrasi yang baik dan benar dapat digunakan sebagai bahan informasi bagi intern kelompok tani maupun pihak luar yang berkaitan dengan kelompok tani yang bersangkutan. Adapun perangkat administrasi yang berhasil dibuat pada setiap 
kelambagaan tani di masing-masing desa adalah :1) Buku Induk Anggota Kelompok, 2) Buku Tamu, 3) Buku Daftar Hadir Pertemuan, 4) Buku Notulensi Rapat, 5) Buku Kegiatan, 6) Buku Inventaris Barang, 7) Buku Iuaran Anggota, dan 8) Buku Kas Umum Kelembagaan Tani.

\section{KESIMPULAN}

Dalam kegiatan pengabdian pada masyarakat tani dalam bentuk pendampingan ini dapat disimpulkan bahwa telah terjadi peningkatan kapasitas kelembagaan tani sejalan dengan meningkatnya pengetahuan, sikap dan keterampilan dari para anggota dari kelemgaan tani tersebut dalam hal pembenahan adminitrasi pembukuan, yang tadinya belum sama sekali atau sudah tetapi belum tertata dengan baik, sekarang telah memiliki buku-buku administrasi yang mereka perlukan agar perkembangan kelembagaan tani yang mereka ikuti dapat tercatat dan terpantau terus demi kelembagaan tani yang kuat, tangguh dan mandiri.

Hendaknya kegiatan pendampingan ini masih dapat terus dilaksanakan secara kontiue oleh seluruh widyaiswara yang mendapatkan tugas untuk melatih petani serta PPL (Petugas Penyuluhan Pertanian) dapat terus melakukan pemantauan serta pembimbingan lanjutan melalui penyuluhan yang intens agar gerak kemajuan petani yang berada didaerah food estate dapat terus terpantau sehingga program ini dapat berjalan dengan baik dan tercapai tujuan yg diinginkan yaitu ketahanan pangan bagi seluruh rakyat Indonesia.

\section{DAFTAR PUSTAKA}

Aria RA, Hasanuddin T \& Prayitno RT. (2016). Peranan Penyuluh Pertanian Lapangan (Ppl) Terhadap Keberhasilan Program Pengembangan Usaha Agribisnis Pedesaan (Puap) Di Kecamatan Sungkai Selatan, Kabupaten Lampung Utara. Jurnal Ilmu Ilmu Aagribisnis. Vol 4, No. 4 Oktober 2016. From http://jurnal.fp.unila.ac.id/index.php/JIA/article/view/1526/1380

Effendi L dan Apriani Y. (2018). Motivasi Anggota Kelompok Tani Dalam Peningkatan Fungsi Kelompok. Jurnal Ekonomi Pembangunan. Vol. 4, No. 12018 10-24. From http://journal.stiem.ac.id/index.php/jurep/index

Hermanto dan Swastika Dewi KS. (2011). Farmers'Groups Empowerment as an Initial Step to Farmers' Welfare Improvement. Jurnal Analisis Kebijakan Pertanian. Vol 9(4): Pusat Sosial Ekonomi dan Kebijakan Pertanian Bogor (ID). From http://pse.litbang.deptan.go.id/ind/pdffiles/ART9-4e.pd

Kemetan. (2014). From http://cybex.pertanian.go.id/materipenyuluhan.

Kementan. (2020). Food Estate Kalteng Ungkit Kesejahteraan Petani. Jakarta. From https://www.pertanian.go.id/home/?show=news\&act=view\&id=4633.

Nuryati S dan Swastika D. (2011). Peran Kelompok Tani Dalam Penerapan Teknologi

Pertanian. Forum Penelitian Agro Ekonomi Pusat Sosial Ekonomi dan Kebijakan Pertanian Ejurnal Litbang. Vol. 29 No.2 Desember 2011:115-120. From http://ejurnal.litbang.pertanian.go.id/index.php/fae/article/view/3896/3238

Permentan Nomor 82 tahun 2013 tentang Kelompok Tani dan Gabungan Kelompok Tani.

Permentan No. 37/SM.120/8/2018 Tentang Pedoman Pelatihan Pertanian.

Sumodiningrat G. (1999). Pemberdayaan Masyarakat dan Jaringan Pengamanan Sosial. Jakarta: PT Gramedia Pustaka Utama.

Suteno dan Rabiansyah H. (2020). Draf Pembukuan dan Administrasi Kelompok Tani Program Readsi Kab. Sambas dan Kab. Sanggau Provinsi Kalimantan Barat. Kalbar.

Zarella, D. (2010). The social media marketing book. Jakarta: PT Serambi Ilmu Semesta Anggota IKAPI. 